ИЗВЕСТИЯ АКАДЕМИИ НАУК ЭСТОНСКОИ ССР. ТОМ 30 Химия. 1981, № 4

\title{
АНАЛИЗ СМОЛЫ ЛАБОРАТОРНОГО ПОЛУКОКСОВАНИЯ ГОРЮЧЕГО СЛАНЦА ЧАГАНСКОГО МЕСТОРОЖДЕНИЯ
}

Горючий сланец чаганского месторождения Оренбургской области до настоящего времени мало изучен. С точки зрения генезиса органического вещества горючих сланцев и их практического использования большой интерес представляет анализ смолы, полученной из этих сланцев. Цель настоящей работы - исследование группового и индивидуального составов смолы хроматографическими и спектральными методами, а также изучение углеводородных скелетов сернистых соединений смолы каталитическим гидрированием на комбинированной микрореакторно-хроматографической установке.

Сланщеносная толща чаганского месторождения представлена тремя пачками битуминозных глин, включающих в себя пласты горючих сланцев, разделенных известковистыми глинами с прослойками известняков. Мощность сланценосной толщи достигает 30 , мощности пластов и пропластков горючих сланцев варьируют от нескольких сантиметров до $3,5 \mu$. Глубина залегания кровли сланценосной толщи от поверх: ности находится от $0 M$ на севере до $300 M$ на юге. Лучшие по качеству - сланцы верхнего пласта месторождения (мощность пласта $0,9-1,3 \mu$; теплотворная способность сланца $3500-4600 \kappa \kappa a л / \kappa 2)$ и нижнего (мощность пласта $1-3$; ; теплотворная способность сланца $2100-3000 \kappa \kappa a л / \kappa 2)$.

Исследуемая проба была отобрана из верхнего плласта горючих сланцев скважины № 45/10, для чего было изъято $3 / 4$ керна, получеюного по пластопересечению. Проба была доставлена в Институт химии АН ЭССР сотрудниками нежинской геолого-гидрогеологической экспедиции.

Ввиду того, что чаганский сланец и полученная из него смола высокосернисты, будет интересно сравнить эту смолу с другими, более изученными смолами, полученными как из низкосернистого эстонского горючего сланца-кукерсита, так и из высокосернистого кашпирского сланца. Географически чаганское месторождение расположено в достаточной близости от кашпирского. Данные о смолах этих месторождений приводятся в ряде литературных источников [ $\left.{ }^{1-4}\right]$.

Полукоксование сланца проводилось в стандартных условиях (ГОСТ 3168-66) в лабораторной алюминиевой реторте. Содержание серы в смоле определялось колбовым методом [5], элементный анализ проводился в соответствующем аппарате фирмы Хьюлетт-Паккард, ИК-спектры смол снимались на спектрофотометре UR-10 фирмы Карл Цейсс.

Для выделения фенолов смола обесфеноливалась двукратным избытком $10 \%$-ного водного раствора гидроокиси натрия.

1 ENSV TA Toimetised. K 41981 
Таб̆лица 1

Характернстика исходного горючего сланца, \%

\begin{tabular}{|c|c|c|c|c|}
\hline \multirow{3}{*}{ Показатель } & \multicolumn{4}{|c|}{ Название горючего сланца } \\
\hline & \multirow{2}{*}{ чаганскнй } & \multicolumn{2}{|c|}{ кашнирский } & \multirow{2}{*}{$\begin{array}{c}\text { кукерсит } \\
{\left[{ }^{1}\right]}\end{array}$} \\
\hline & & {$[3]$} & {$\left[{ }^{2}\right]$} & \\
\hline $\begin{array}{l}\mathrm{W}^{\mathrm{a}} \\
\mathrm{A}^{\mathrm{c}} \\
\left(\mathrm{CO}_{2}\right)_{\text {карбонтиая }}^{\mathrm{c}} \\
\mathrm{Se}\end{array}$ & $\begin{array}{r}2,9 \\
35,7 \\
7,6 \\
8.3\end{array}$ & $\begin{array}{c}4,8 \\
74,3 \\
10,2 \\
2,58\end{array}$ & $\begin{array}{r}6,7 \\
46,9 \\
17,2 \\
6,4\end{array}$ & $\begin{array}{r}2,9 \\
46,3 \\
15,6 \\
29\end{array}$ \\
\hline $\mathrm{S}_{\text {о6 }}^{\mathrm{e}}$ & $\begin{array}{r}8,3 \\
-6-7\end{array}$ & 2,58 & 6,4 & 2,2 \\
\hline $\begin{array}{l}\text { Условная органическая масса } \\
\text { Элементный состав органического веще- } \\
\text { ства: }\end{array}$ & 56,7 & 15,5 & 35,9 & 38,1 \\
\hline $\begin{array}{c}\mathrm{C} \\
\mathrm{H} \\
\mathrm{N} \\
\mathrm{O} \\
\mathrm{S} \\
\text { Атомное отношение } \mathrm{H} / \mathrm{C}\end{array}$ & $\begin{array}{r}64,5 \\
7,8 \\
0,9 \\
26,8 \\
1,44\end{array}$ & & $\begin{array}{c}65,1 \\
7,7 \\
0,9 \\
14,6 \\
11,7 \\
1,41\end{array}$ & $\left\{\begin{array}{r}77,7 \\
9,4 \\
12,8 \\
1,44\end{array}\right.$ \\
\hline
\end{tabular}

Табмица 2

Характернстнка смолы полукоксөвання сланца

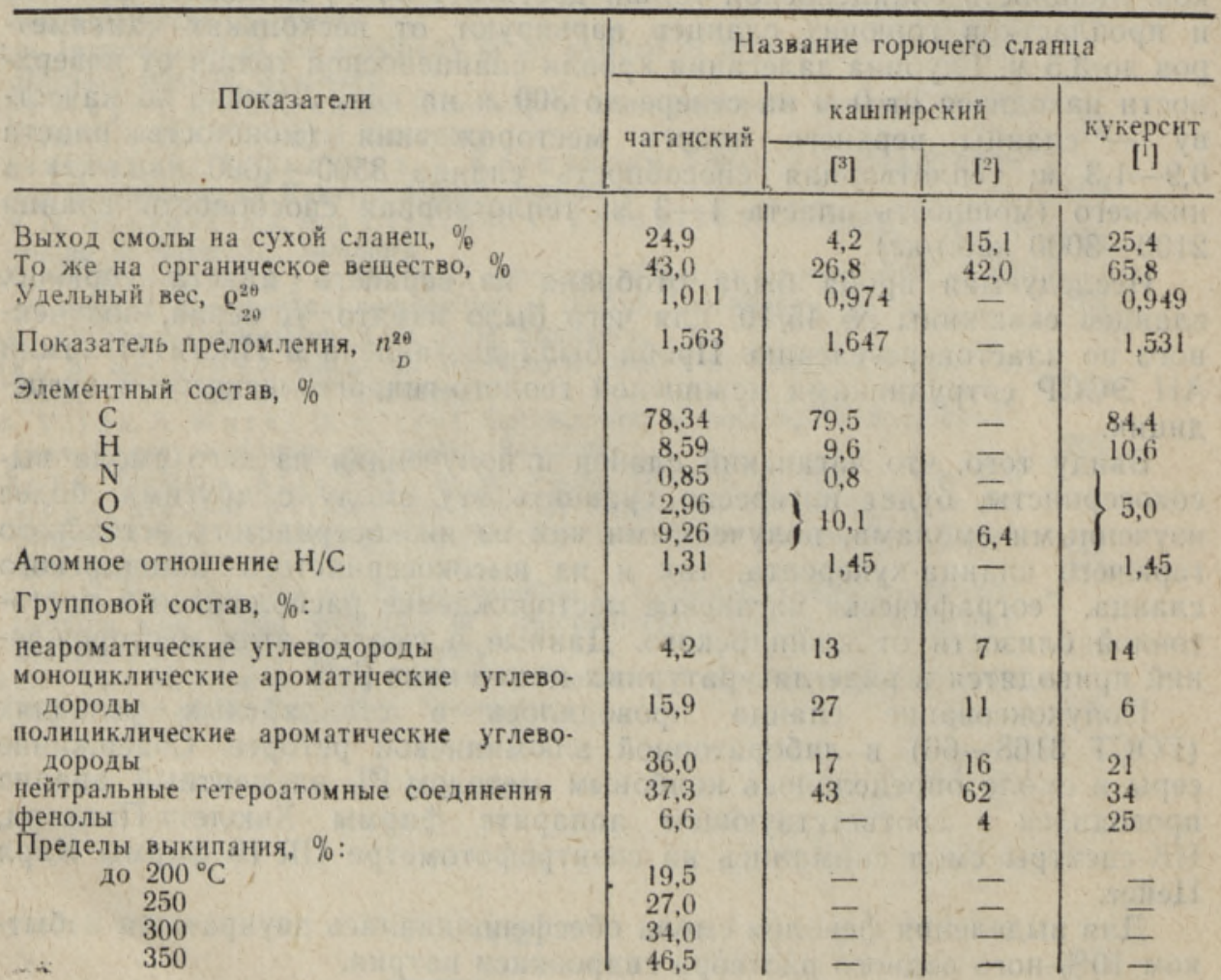




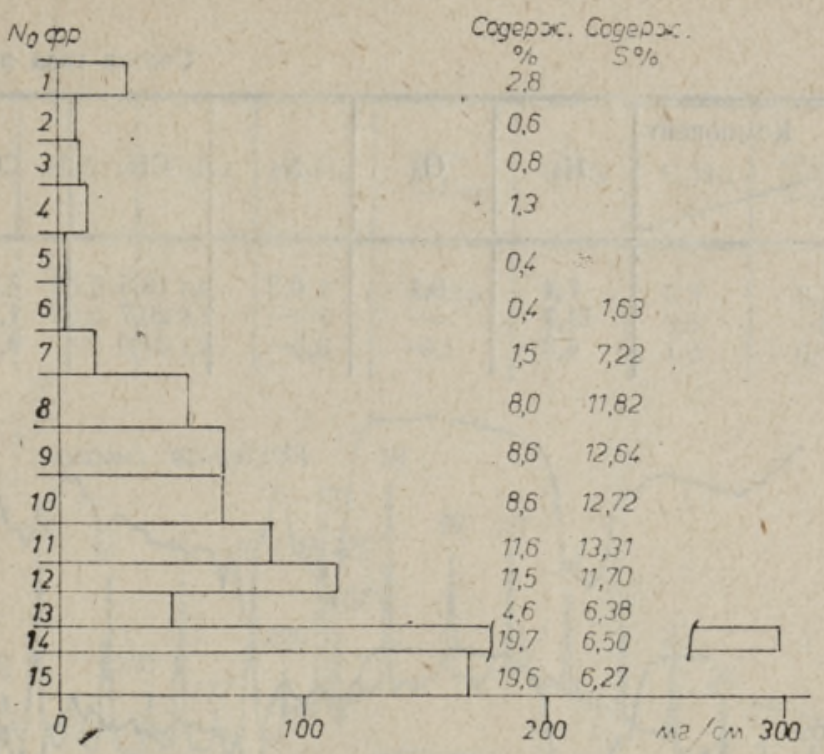

Рис. 1. Распределение смолы в сухой колонке.

Для определения химического группового состава смола хроматографировалась на силикагеле $L$ (Чехословакия) $40-100$ мкм и на окиси алюминия, по Брокману II (Венгрия) с использованием метода сухой колонки [6], в 50-сантиметровой стеклянной колонке (Ø25 мм), с употреблением в качестве сольвента $\boldsymbol{H}$-гексана, поднимавшегося при темнературе $+3{ }^{\circ} \mathrm{C}$ в течение трех часов. Таким образом были выделены 15 фракций, отличавшиеся друг от друга по признакам отдельных химических групп (разноцветные зоны в условиях дневного и УФ-света, реакция на присутствие алкилбензолов).

Суммарная смола, ее группы и фенолы анализировались газохроматографически на аппарате «Хром-41» в условиях программирования температуры, газ полукоксования - на аппарате УХ-1 с катарометром. Газ-носитель - гелий. Характеристика исходного горючего сланца представлена в табл. 1, смолы его полукоксования - в табл. 2.

Чаганский сланец принадлежит к группе высокосернистых сланцев, высокосерниста также и его смола. Содержание серы в смоле оказывается даже бо́льшим чем в исходном сланце. Для сравнения упомянем, что серы в смоле полукоксования кукерсита содержится меньше, а в случае кашпирского сланца - столько же, сколько и в исходном сланце. В отличие от других высокосернистых сланцев, в чаганском сланце отмечается высокое содержание органического вещества.

Выход смолы чаганского сланца, в расчете на органическое вещество, близок к выходу смолы из кашпирского сланца, выход смолы из кукерсита значительно выше. Этот факт согласуется с отмеченной ранее закономерностью, согласно которой выход смолы высокосернистых сланцев относительно низок. Газ полукоксования чаганского сланца (табл. 3) отличается от получаемого из кашпирского и эстонского сланцев газа пониженной концентрацией в нем двуокиси углерода и повышенной - сероводорода.

Распределение смолы во фракции сухой колонки на силикагеле $L$ представлено графически на рис. 1. Там же приведено и содержание серы в отдельных фракциях смолы. По данным хроматографирования, 
Состав газа полукоксования

\begin{tabular}{|c|c|c|c|c|c|c|}
\hline $\begin{array}{l}\text { Название } \\
\text { смолы }\end{array}$ & $\mathrm{H}_{2}$ & $\mathrm{O}_{2}$ & $\mathrm{~N}_{2}$ & $\mathrm{CH}_{4}$ & $\mathrm{CO}$ & $\mathrm{CO}_{2}$ \\
\hline $\begin{array}{l}\text { Чаганский } \\
\text { Кашпирский }\left[{ }^{3}\right] \\
\text { Кукерсит ['] }\end{array}$ & $\begin{array}{r}7,4 \\
11,7 \\
4,3\end{array}$ & $\frac{0,1}{-}$ & $\frac{0,2}{-}$ & $\begin{array}{l}18,5 \\
20,7 \\
31,0\end{array}$ & $\begin{array}{l}3,2 \\
1,3 \\
9,7\end{array}$ & $\begin{array}{r}7,8 \\
21,2 \\
21,7\end{array}$ \\
\hline
\end{tabular}
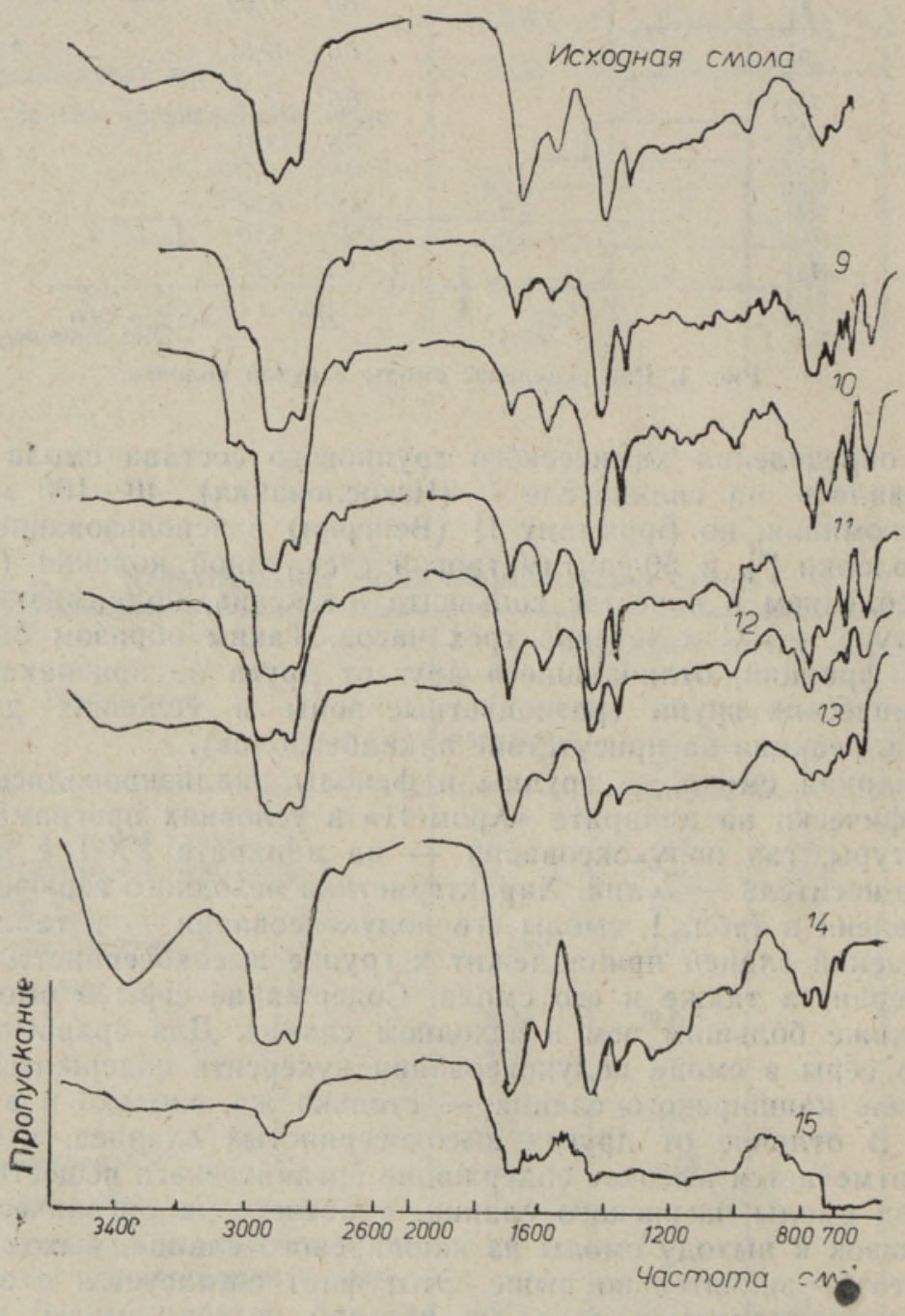

Рис. 2. ИК-спектры смолы полукоксования и выделенных в сухой колонке фракций 9-15.

представленный групповой состав (табл. 2) приблизителен, так как все фракции, кроме неароматических углеводородов, содержат в значительном количестве серу, причем главная масса серы (серусодержащие соединения) сконцентрирована во фракщиях ароматических угле- 
сланца, об. \%

\begin{tabular}{|c|c|c|c|c|c|c|c|c|c|}
\hline $\mathrm{C}_{2} \mathrm{H}_{4}$ & $\mathrm{C}_{2} \mathrm{H}_{6}$ & $\mathrm{H}_{2} \mathrm{~S}$ & $\mathrm{C}_{3} \mathrm{H}_{6}$ & $\mathrm{C}_{3} \mathrm{H}_{8}$ & $\begin{array}{c}\text { изо- } \\
\mathrm{C}_{4} \mathrm{H}_{40}\end{array}$ & $\mathrm{C}_{4} \mathrm{H}_{8}$ & $\mathrm{C}_{4} \mathrm{H}_{40}$ & $\begin{array}{l}\text { транс- } \\
\mathrm{C}_{4} \mathrm{H}_{8}\end{array}$ & $\begin{array}{c}u u c- \\
\mathrm{C}_{4} \mathrm{H}_{8}\end{array}$ \\
\hline $\begin{array}{l}0,7 \\
3,2 \\
3,8\end{array}$ & $\begin{array}{r}2,6 \\
5,0 \\
14,4\end{array}$ & $\begin{array}{l}56,5 \\
30,9 \\
-\end{array}$ & $\begin{array}{l}1,0 \\
2,1 \\
4,9\end{array}$ & $\begin{array}{l}1,2 \\
2,4 \\
5,6\end{array}$ & $\frac{\text { следы }}{0,1}$ & $\begin{array}{l}0,3 \\
0,9 \\
1,7\end{array}$ & $\begin{array}{l}0,3 \\
0,6 \\
1,9\end{array}$ & $\frac{0,1}{0,5}$ & $\frac{0,1}{0,4}$ \\
\hline
\end{tabular}

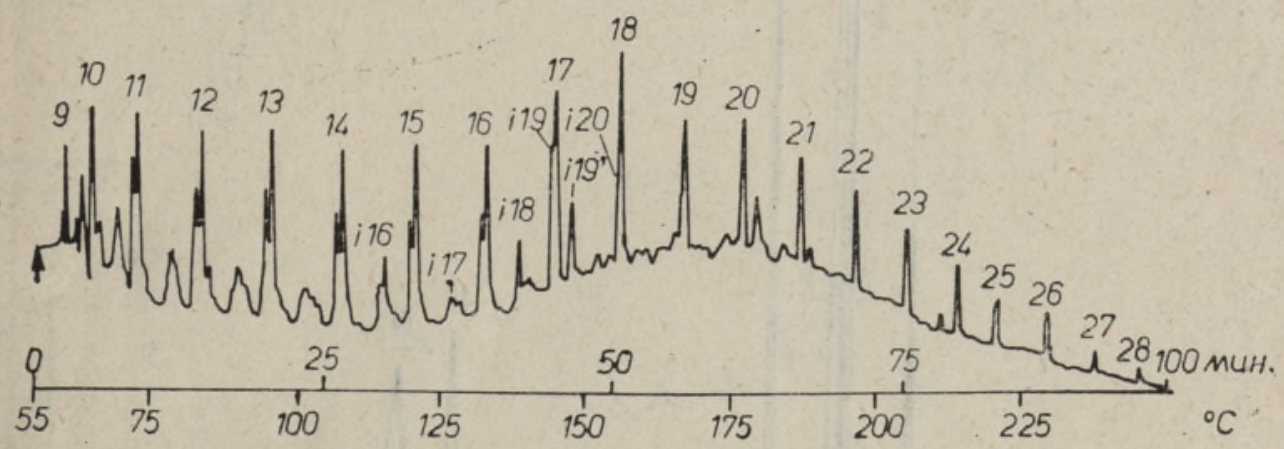

Рис. 3. Хроматограмма фракции неароматических углеводородов смолы полукоксования. Цифры 9-28 указывают на число атомов углерода в молекуле н-алкана и н-алкена; 116 - $i 20$ - насыщенные изопреноидные углеводороды; $i 19^{\prime}$ - пристен. Колонка: 15 м, $\varnothing$ 0,25 мм, дексил 300, подъем температуры колонки - 2 град/мин

водородов. В смоле чаганского сланца над другими компонентами превалируют ароматические соединения. Низкое значение отношения H/C в смоле указывает также на повышенную ее ароматичность, еще раз подтверждая закономерность повышенного содержания ароматических углеводородов в смоле полукоксования высокосернистых сланцев. Для полученных спектров характерны как полосы поглощения 2850$2960 \mathrm{CM}^{-1}$, так и 1385 и $1440 \mathrm{CM}^{-1}$ (рис. 2), что указывает на присутствие $\mathrm{CH}_{3}$ - и - $\mathrm{CH}_{2}$-групп, а в то же время и на наличие длинных углеводородных цепей в молекуле. Кроме того в ИК-спектрах присутствует также полоса поглощения $1600 \mathrm{~cm}^{-1}$, характерная для ароматического ядра. Интенсивность поглощения в области ИК-спектра 1710 и $3400-3500 \mathrm{~cm}^{-1}$, приходящаяся на кислородсодержащие фракции, возрастает по мере увеличения адсорбции содержащихся в смоле соединений, причем первая область поглощения характеризуется присутствием карбонильной и вторая - гидроксильной групп. Получение характерных данных с помощью ИК-спектроскопии относительно сернистых соединений в смоле вообще и их структуры в особенности затруднено. Фракции смолы характеризуются ИК-спектрами лишь в самом общем виде.

Неароматические углеводороды смолы (рис. 3) выделены на тонком слое силикагеля 40-100 мкм (пластинка $24 \times 24 \mathrm{~cm}$, толщина слоя адсорбента - 2 мм, растворитель - н-гексан). Неароматические углеводороды смолы представлены гомологическим рядом $H$-алканов с не-

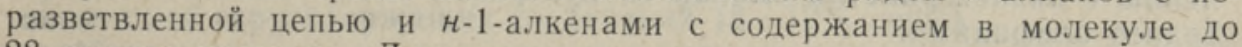
28 атомов углерода. Для углеводородов с количеством атомов до $\mathrm{C}_{16}$ концентрация индивидуальных алканов относительно равная, в максимальном количестве - углеводороды с 17-18 углеродными атомами 


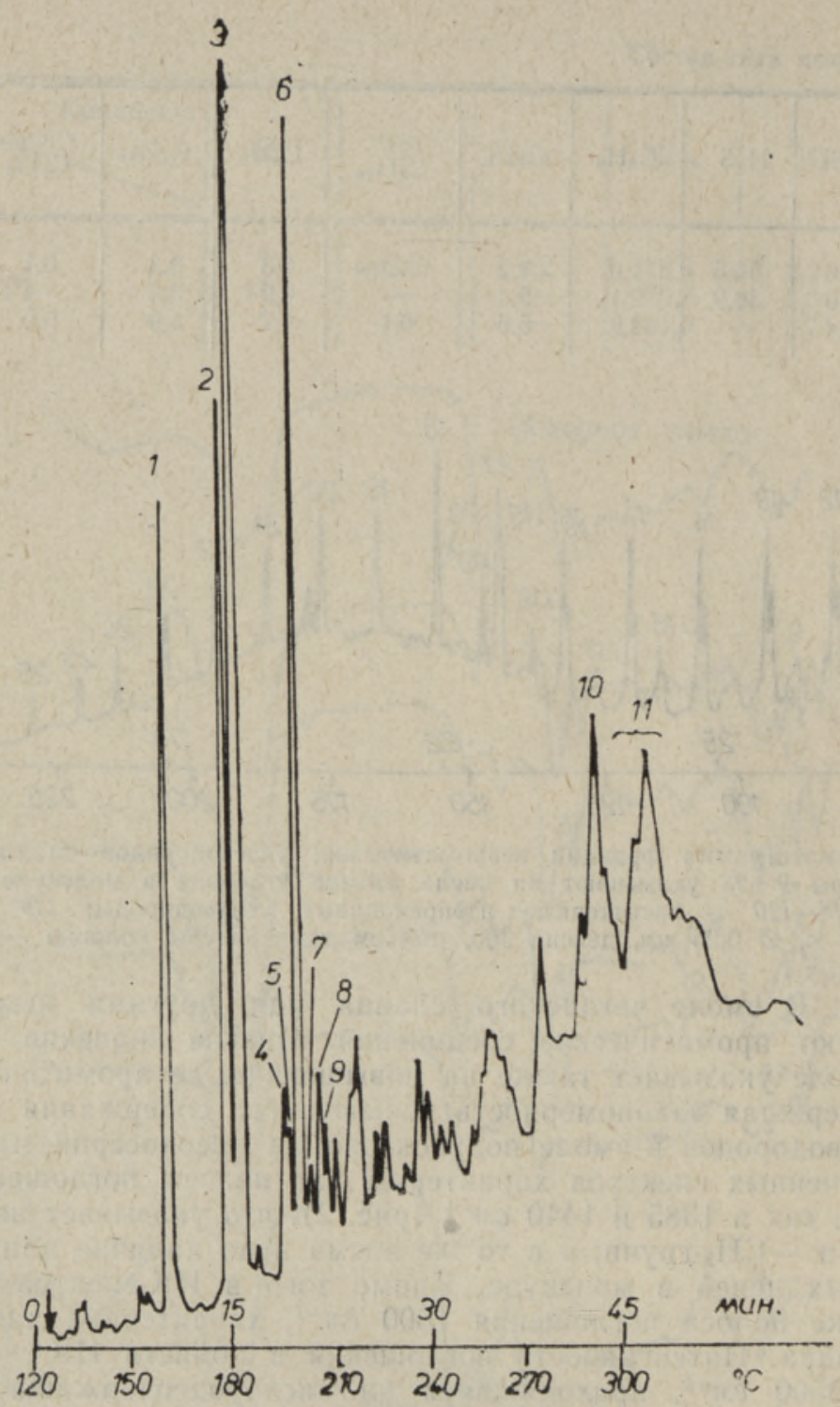

Рис. 4. Хроматограмма фенолов. Колонка: 3,7 м, $\varnothing 3$ мм, $5 \%$ апиезона $L$ на инертоне AW HMDS $(0,250-0,315$ м.м. .1 фенол; 2 - 2-метилфенол; 3 - 3- и 4-метилфенолы; 4 2 -этилфенол; $5-2,6$ диметилфенол; $6-2,4$ - и 2,5-диметилфенолы, 3- и 4-этилфенолы; 7 - 3,5-диметилфенол; 8 2,3-диметилфенол; $9-3,4$-диметнлфенол; $10-1$ - и 2-нафтолы; 11 - метилнафтолы.

в цепи. Концентрация углеводородов свыше $\mathrm{C}_{23}$ резко падает. По сравнению с низкосернистой смолой из кукерсита смола чаганского сланца беднее олефинами.

В смоле чаганского сланца содержатся изопреноидные углеводороды $\mathrm{C}_{16}-\mathrm{C}_{20}$, концентрация которых выше чем в смоле из кукереита. Превалирующие в смоле моноциклические ароматические углеводороды 


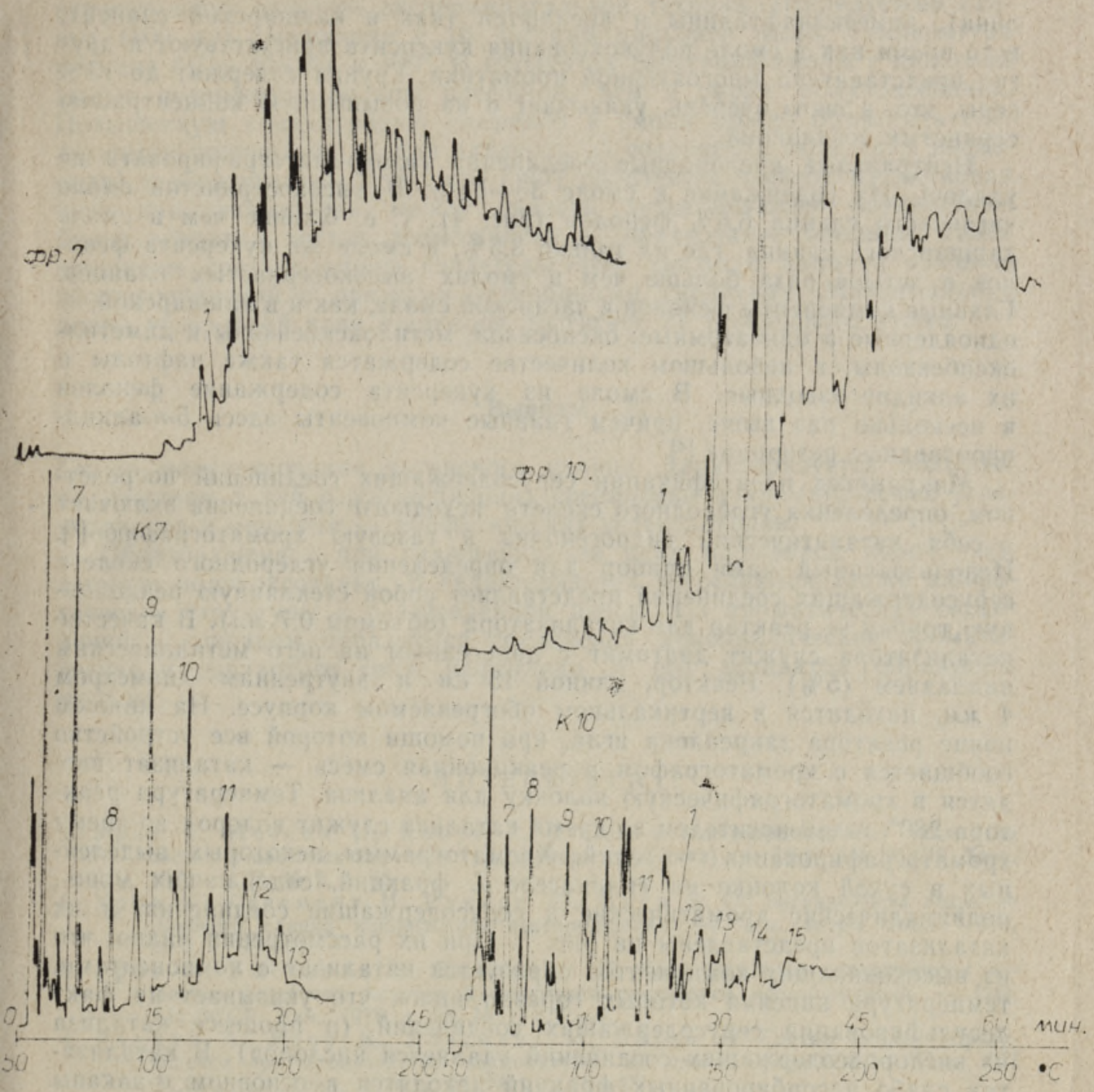

Рнс. 5. Хроматограммы выделенных на сухой колонке фракций 7 и 10, и нх катализатов ( 7 и 7 10). Колонка: 3,6 м, ஜ 3 м., $7 \%$ Е 301 на щелите $545(0,125$ 0,160 мм), подъем температуры колонки - 4 град/мин $I-$ нафталин, цифры $7-15$ указывают на число атомов углерода в молекуле н-алкана.

концентрируются в низкокипящей ее части, что придает ей сходство со смолой кашпирского сланща. Обе эти смолы отличаются от кукерситной, в низкокипящей части которой преобладают алифатические углеводороды. Моноциклические ароматические углеводороды имеют сложный состав, но главные их компоненты - первые гомологи одноядерных ароматических углеводородов - бензол, толуол, этилбензол, $M-, n$ - и $\boldsymbol{o}$-ксилолы, пропил- и бутилбензолы. Состав моноциклических ароматических углеводородов в смоле еще более усложняется присутствием в ней серусодержащих соединений $(8-10 \%$ серы).

Полициклические ароматические углеводороды смолы полукоксования чаганского сланца содержат нафталин, 1- и 2-метилнафталины (концентрация 2-метилнафталина выше концентрации 1-метилнафта- 
лина), диметилнафталины и аценафтен (как и кашпирский сланец), в то время как в смоле полукоксования кукерсита присутствуют и другие представители многоядерной ароматики. Группа содержит до $13 \%$ серы, это, в свою очередь, указывает и на повышенную концентрацию сернистых соединений.

Нейтральные кислородные соединения газохроматографировать не удалось. Их содержание в смоле $35-55 \%$. В высокосернистой смоле чаганского сланца $6,6 \%$ фенолов (рис. 4), т. е. больше чем в смоле кашпирского сланца, где их только $3,5 \%$, в смоле же кукерсита фенолов в четыре раза больше чем в смолах высокосернистых сланцев. Главные компоненты фенолов в чаганской смоле, как и в кашпирской, одноядерные и одноатомные: оксибензол, метилоксибензолы и диметилоксибензолы, в небольшом количестве содержатся также нафтолы и их алкилпроизводные. В смоле из кукерсита содержание фенолов в несколько раз выше, причем главные компоненты здесь 5-н-алкилпроизводные резорцина [4].

Микрометод идентификации серусодержащих соединений посредством определения углеродного скелета исходного соединения включает в себя каталитический гидрогенолиз и газовую хроматографию [7]. Использованный нами прибор для определения углеродного скелета серусодержащих соединений представляет собой стеклянную реакционную трубку - реактор для катализатора (объемом 0,7 мл). В качестве катализатора служит диатомит с нанесенным на него металлическим палладием $(5 \%)$. Реактор, длиной 15 cм и внутренним диаметром 4 мм, находится в вертикальном обогреваемом корпусе. На нижнем конще реактора закреплена игла, при помощи которой все устройство сообщается с хроматографом и реакционная смесь - катализат вводится в хроматографическую колонку для анализа. Температура реактора $280^{\circ}$, газом-носителем во время катализа служит водород, во время хроматографирования - гелий. Хроматограммы некоторых выделенных в сухой колонке на сиंликагеле $L$ фракций, содержащих моно-, полициклические ароматические и серусодержащие соединения, и их катализатов представлены на рис. 5. При их рассмотрении видно, что из высококипящих компонентов образуется катализат с компонентами, температура кипения которых гораздо ниже, что указывает на факт десульфирования серусодержащих соединений (в процессе катализа из кислородсодержащих соединений удаляется кислород). В катализатах слабо адсорбированных фракций находятся в основном $н$-алканы $\mathrm{C}_{7}-\mathrm{C}_{15}$. В катализатах сильно адсорбированных соединений - также ароматические соединения с более низкой молекулярной массой. С увеличением адсорбции содержащихся во фракции компонентов в катализате удлиняются боковые цепи соединений бензольного ряда. Полученные по углеродному скелету данные позволяют предположить присутствие в слабо адсорбированных фракциях алифатических сульфидов (или меркаптанов) и в более сильно адсорбированных - соединений c ароматической структурой и даже соединений с двумя атомами серы. В сильно адсорбированных фракциях содержание серы снижается, так как фракции содержат более полярные гетероатомные кислородные соединения. С помощью вышеупомянутого метода анализа в катализате можно определять длину углеводородных цепей $H$-алканов вплоть до $\mathrm{C}_{15}$, соединения с длинными цепями задерживаются на катализаторе [8].

Одним из методов установления структуры углеродного скелета кислород- и серусодержащих соединений считается также и метод перегонки с цинковой пылью []. Преимущество этого метода состоит в 
относительной простоте экспериментальной техники. Исследуемый сланец (100 мг) смешивали с 10 частями цинковой пыли. Температура реакции была близка к $400^{\circ}$. В продуктах перегонки смолы с цинковой пылью содержится больше олефинов, чем в смоле полукоксования. Повышенную концентрацию олефинов в смоле можно объяснить следующими причинами: а) при удалении из соединения серы (или кислорода) с образованием $\mathrm{ZnS}$ (или $\mathrm{ZnO}$ ) образуется олефин; б) цинковая пыль как катализатор может оказать дегидрирующее воздействие. Более вероятна первая возможность - образование олефина. Такое изменение состава смолы свидетельствует также о наличии в смоле гетеросоединений с прямыми углеродными скелетами. Максимальная длина углеродной цепи $H$-алканов достигает 21 углеродного атома.

\section{Выводы}

Смола полукоксования чаганского сланца характеризуется бо́льшим количеством в ней серусодержащих соединений и ароматических углеводородов и меньшим - алифатических углеводородов.

Образовавшиеся при гидрогенизации цепи парафинов короче чем в смоле полукоксования. В гидрогенизатах встречаются также алифатические структуры с разветвленной цепью. Из ароматических соединений в основном образуются соединения моноциклические ароматические и инданового типа; нафталина и его дериватов образуется меньше.

\section{Л И ТЕ РА Т У Р А}

1. Уров К., Нечаев И., Я анус А. О влиянии конщентрированных кислот на состав и свойства керогена (на примере кукерсита). - Изв. АН ЭССР, Хим., 1979, т. 28 , № 2, с. $55-70$.

2. Уров К., Клесмент И., Р иккен Ю., Мяги Э. Об органическом веществе горючего сланца кашпирского месторождения. - Хим. тверд. топл., 1976, № 2, c. $63-69$.

3. Уров К,, Высоцкая В., Клесмент И. Характеристика органического вещества нерабочих пластов Кашпирского сланцевого месторождения. - Изв. АН ЭССР, Хим., 1979, т. 28 , № 1, с. $1-6$.

4. Р яндур А., Уров К., Клесмент И., Эйзен О. Состав смолы, образующейся при производстве термобитума из сланца-кукерсита. - Изв. АН ЭССР, Хим. Геол., 1976, т. 25, № 1, с. $10-15$

5. К орч а г н а Ю. И., Ч т в ер и Ков а О. П. Колбовый метод определения галогенов и серы. - В кн.: Методы исследования рассеянного органического вещества осадочных пород. М., 1976, с. 104-121.

6. К лесмен т И., К и в р яхк С. Использование хроматографии в сухой колонке для исследования состава жидких продуктов переработки твердого топлива. Тез. докл. III всесоюз. конф. по анал. хим., Мннск, 1979 , ч. 2, с. $343-344$.

7. В игдергауз M. С. Анализ неуглеводородных составляющих нефти. - В кн.: Газовая хроматография как метод исследования нефти. М., 1973, с. $181-198$.

8. Бере зкин В. Г. Определение углеродного скелета органических соединений. В кн.: Химические методы в газовой хроматографии. М., 1980, с. 119-136.

9. В а лен т а 3. Перегонка с цинковой пылью. - В кн.: Установление структуры органических соединений физическими и химическими методами. М., 1967, ч. 2 , с. $221-231$.

Ннститут химии

Академии наук Эстонской ССР
Поступила в редакцию $8 /$ XII 1980 
Saima SALUSTE, I. KLESMENT

\section{TŚAGANSKI LEIUKOHA POLEVKIVI LABORATOORSEL UTMISEL TOODETUD OLI ANALUOS}

On esitatud elemendianalüüsi, infrapunase spektroskoopia ja gaasikromatograafia abil saadud andmed kuivas kolonnis silikogeelil L lahutatud ôli grupi- ja individuaalkoostise kohta. Väävliübendite süsinikskeleti määramisel kasutati hüdrogeenimist mikroreaktor-gaasikromatograafis. Oli iseloomustab suur aromaatsete süsivesinike ja väävliühendite sisaldus.

Saima SALUSTE, I. KLESMENT

\section{ANALYSIS OF THE OIL PRODUCED BY LABORATORY SEMI-COKING OF THE TSHAGANSK OIL SHALE}

The data oblained by elemental analysis, IR-spectroscopy, and gas chromatography characterize group and individual composition of oil separated by dry column chromatography on Silica gel L. Hydrogenation in a microreactor-gas chromatograph is used to determine the carbon skeleton of sulphur compounds. A high concentration of aromatic hydrocarbons and sulphur compounds $(9.3 \%$ sulphur $)$ is characteristic of this oil.

The aliphatic hydrocarbons of the discussed oil are represented by a homologous series of $n$-alkanes and $n$-alkenes containing up to 28 carbon atoms in the molecule. Monocyclic aromatic hydrocarbons have a high concentration in the low-boiling part of oil, the main ingredients forming short side chains. Polycyclic aromatics contain naphthalene, methylnaphthalenes and acenaphthene.

The concentration of neutral oxygen compounds is $40 \%$, and that of phenols $6.6 \%$. Phenols are represented by monocyclic and monohydroxy derivatives. 